\title{
OGRANICZENIA PRAWA DO ODLICZENIA PODATKU NALICZONEGO: REALIZACJA ZASADY NEUTRALNOŚCI A FUNKCJA FISKALNA VAT
}

Streszczenie. Z przeprowadzonych rozważań wynika, że istnieje swego rodzaju konflikt pomiędzy realizacją zasady neutralności a funkcją fiskalną podatku od towarów i usług. W zakresie przestrzegania tej zasady ustawodawca jest związany przepisami obowiązującymi w Unii Europejskiej, do których stosowania Polska, jako państwo członkowskie, jest zobowiązana. Niemniej jednak w niektórych obszarach prawo to pozostawia pewną swobodę kształtowania własnego systemu podatkowego. W zakresie tej swobody, jak wynika $\mathrm{z}$ dokonanej analizy, podstawowym kryterium przy podejmowaniu decyzji dotyczących kierunków zmian w zakresie podatku od towarów i usług była funkcja fiskalna podatku. Konieczność zapewnienia dochodów budżetowych na określonym poziomie zawsze będzie priorytetem dla każdej władzy państwowej, lecz realizacja funkcji fiskalnej podatku od towarów i usług powinna zawsze być konfrontowana $\mathrm{z}$ koniecznością realizacji jednej z fundamentalnych cech tego podatku, tj. zasadą neutralności podatku, która przejawia się m.in. w prawie do pomniejszenia podatku należnego o podatek naliczony zawarty w nabywanych towarach lub usługach. Potwierdza to, że zakres respektowania zasady neutralności w konstrukcji podatku od towarów i usług ma istotne znaczenie dla realizacji funkcji fiskalnej tego podatku.

* Doktor nauk ekonomicznych, Katedra Finansów Publicznych, Wydział Finansów i Ubezpieczeń, Uniwersytet Ekonomicznych w Katowicach, e-mail: roman.namyslowski@ gmail.com 
Słowa kluczowe: realizacja zasady neutralności, funkcja fiskalna, podatek od towarów i usług, ograniczenie prawa do pomniejszenia podatku należnego o podatek naliczony, usługi restauracyjne, usługi zakwaterowania

Klasyfikacja JEL: E62

\section{WPROWADZENIE}

Podstawowym instrumentem pozyskiwania środków pieniężnych do realizacji zadań publicznych są obecnie podatki. $Z$ tego względu podstawową funkcją podatków w prawidłowo funkcjonującym systemie finansów publicznych jest funkcja fiskalna. Efektywność podatków jako instrumentu fiskalnego - dla zapewnienia odpowiedniego poziomu dochodów budżetu państwa - wynika przede wszystkim z cech podatku jako przymusowego świadczenia, którego zapłata może być zapewniona w ostateczności poprzez stosowanie określonych środków przymusu. Spośród stosowanych obecnie przez kraje rozwinięte form opodatkowania jednym z najbardziej skutecznych narzędzi zaspokajania popytu państwa na pieniądz jest podatek od wartości dodanej, w Polsce określany jako podatek od towarów i usług ${ }^{1}$. Sprawia to przede wszystkim konstrukcja tego podatku, a w szczególności neutralność podatku i wynikający z niej mechanizm wzajemnej kontroli podmiotów uczestniczących w obrocie gospodarczym² ${ }^{2}$ Neutralność, przejawiająca się m.in. w prawie do odliczenia podatku naliczonego poniesionego w poprzedniej fazie obrotu, powoduje, że jest on relatywnie tańszym narzędziem niż inne instrumenty podatkowe stosowane przez państwo.

W niniejszym artykule rozważania koncentrują się wyłącznie na wybranych ograniczeniach prawa do odliczenia podatku naliczonego i ich wpływie na realizację funkcji fiskalnej podatku VAT w kontekście planowanych przez Ministerstwo Finansów zmian w tym zakresie, w szczególności przyznania w ograniczonym zakresie prawa do odliczenia podatku naliczonego przy nabyciu usług zakwaterowania.

1 Zob. K. James, The Rise of the Value-Added Tax, Cambridge 2015, s. 25 i n.; J. Aizenman, Y. Jinjarak, The Collection Efficiency of the Value Added Tax: Theory and International Evidence, „The Journal of International Trade \& Economic Development” 2006, nr 15/2.

2 Zob. T. Famulska, Teoretyczne i praktyczne aspekty funkcjonowania podatku od wartości dodanej, Katowice 2007, s. 24. 


\section{ZNACZENIE FISKALNE PODATKU OD TOWARÓW I USŁUG}

DLA FINANSÓW PUBLICZNYCH

Analiza danych liczbowych prowadzi do wniosku, że podstawowym źródłem dochodów budżetu państwa są podatki. To ich wysokość decyduje w zasadniczym stopniu o zakresie i możliwości państwa w realizacji stawianych przed nim zadań. Dla oceny roli podatku od towarów i usług (dalej również: VAT) jako narzędzia pozyskiwania środków pieniężnych przez państwo istotnym wskaźnikiem jest relacja wpływów z tytułu VAT do produktu krajowego brutto $(\mathrm{PKB})^{3}$. Szczegółowe dane w tym zakresie zostały przedstawione na rysunku.

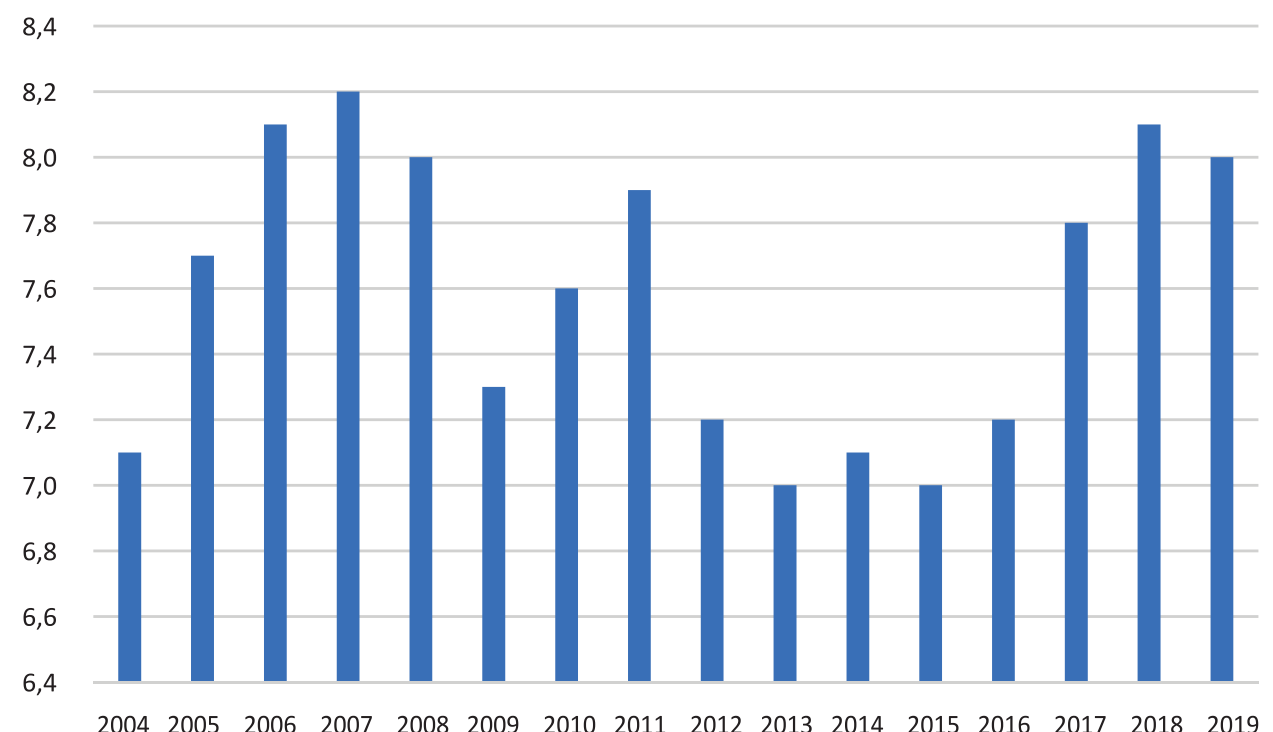

Udział dochodów z tytułu podatku od towarów i usług w PKB w latach 2004-2019 (w \%)

Źródło: opracowanie własne na podstawie danych prezentowanych przez Eurostat na stronie http://ec.europa.eu/eurostat/data/database

Wskaźnik udziału dochodów z tytułu podatku od towarów i usług w PKB w badanym okresie wahał się między 7,0\% w 2013 i 2015 r. (najniższy udział od momentu przystąpienia Polski do Unii Europejskiej (UE)) a 8,2\% w 2007 r. (najwyższy udział). W 2019, ostatnim roku, dla którego

${ }_{3}$ Zob. M.M. Hybka, Determinanty wydajności fiskalnej podatku od wartości dodanej $w$ Niemczech, Poznań 2011, s. 6. 
dostępne są dane, wskaźnik ten wyniósł 8,0\%. Oznacza to, że wskaźnik ten wzrósł o 0,9 punktu procentowego w porównaniu do roku przystąpienia Polski do UE, na co wpływ miały niewątpliwie liczne zmiany legislacyjne, poczynając od podwyższenia stawek podatku o 1 lub 2 punkty procentowe, a kończąc na zmianach, których celem było ograniczenie tzw. luki VAT.

Z kolei analiza danych dotyczących struktury dochodów budżetu państwa w Polsce w latach 2004-2019 (tab. 1) pozwala stwierdzić, że we wskazanym okresie spośród stosowanych w Polsce podatków pośrednich największe znaczenie miał podatek od towarów i usług.

Tabela 1. Udział dochodów z tytułu podatku od towarów i usług w dochodach ogółem budżetu państwa w Polsce, dochodach podatkowych ogółem oraz dochodach z podatków pośrednich w latach 2004-2019 (w \%)

\begin{tabular}{|c|c|c|c|}
\hline \multirow{2}{*}{ Rok } & \multicolumn{3}{|c|}{ Udział dochodów z tytułu podatku od towarów i usług } \\
\cline { 2 - 4 } & $\begin{array}{c}\text { w dochodach } \\
\text { ogółem }\end{array}$ & $\begin{array}{c}\text { w dochodach } \\
\text { podatkowych }\end{array}$ & $\begin{array}{c}\text { w dochodach } \\
\text { Z podatków } \\
\text { pośrednich }\end{array}$ \\
\hline 2004 & 39,84 & 45,93 & 61,65 \\
\hline 2005 & 41,95 & 48,38 & 65,19 \\
\hline 2006 & 42,72 & 48,29 & 66,27 \\
\hline 2007 & 40,76 & 46,68 & 65,78 \\
\hline 2008 & 40,14 & 46,37 & 66,23 \\
\hline 2009 & 36,27 & 46,28 & 64,18 \\
\hline 2010 & 43,10 & 48,47 & 65,31 \\
\hline 2011 & 43,53 & 49,68 & 67,03 \\
\hline 2012 & 41,73 & 48,33 & 65,97 \\
\hline 2013 & 40,63 & 46,93 & 64,67 \\
\hline 2014 & 43,82 & 48,77 & 66,43 \\
\hline 2015 & 42,62 & 47,41 & 65,75 \\
\hline 2016 & 40,23 & 46,34 & 65,34 \\
\hline 2017 & 44,75 & 49,74 & 69,17 \\
\hline 2018 & 46,53 & 50,55 & 71,04 \\
\hline 2019 & 45,74 & 49,88 & 71,68 \\
\hline
\end{tabular}

Źródło: opracowanie własne na podstawie danych publikowanych na stronie http://mf.gov.pl 
Porównując dwa skrajne lata wybranego okresu, czyli lata 2004 i 2019, należy wskazać, że udział podatku od towarów i usług zarówno w dochodach ogółem, dochodach podatkowych, jak i podatkach pośrednich systematycznie wrastał w kolejnych latach, przy czym wzrost ten jest najbardziej zauważalny w ostatniej z analizowanych kategorii, tj. udziale dochodów z tytułu VAT w dochodach z tytułu podatków pośrednich (ponad 10 punktów procentowych). Zauważalna jest zatem rosnąca rola podatku od towarów i usług jako elementu prowadzonej przez państwo polityki podatkowej. Ta dominująca pozycja podatku od towarów i usług z jednej strony pozwala na skoncentrowanie uwagi państwa na zapewnieniu większej skuteczności poboru podatku, z drugiej jednak niewątpliwie zwiększa wrażliwość budżetu państwa na wszelkie działania czy zmiany w gospodarce, których efektem jest zmniejszenie wysokości wpływów z tytułu tego podatku. Jako przykład można tutaj wskazać wyłudzenia w zakresie VAT, będące konsekwencją zarówno działań nieuczciwych przedsiębiorców, jak i wadliwej konstrukcji rozliczania VAT w ramach transakcji towarowych w obszarze Unii Europejskiej.

Podsumowując, z powyższych danych jednoznacznie wynika, że konstrukcja podatku od towarów i usług sprawia, iż podatek ten jest bardzo dobrym narzędziem fiskalnym, zapewniającym stabilność dochodów budżetu państwa.

\section{ZALEŻNOŚCI POMIĘDZY OGRANICZENIAMI PRAWA DO ODLICZENIA PODATKU NALICZONEGO JAKO ELEMENTEM REALIZACJI ZASADY} NEUTRALNOŚCI A FUNKCJĄ FISKALNĄ PODATKU OD TOWARÓW I USŁUG

Istotnym elementem oceny zależności pomiędzy zasadą neutralności a funkcją fiskalną podatku od towarów i usług jest zbadanie wpływu ograniczenia neutralności podatku od towarów i usług (czyli ograniczenia prawa do obniżenia podatku należnego o podatek naliczony przy nabyciu określonych towarów i usług) na realizację funkcji fiskalnej, w szczególności na dochody budżetowe $\mathrm{z}$ tytułu tego podatku. W ramach dokonanej analizy odniosę się wyłącznie do ograniczeń dotyczących usług zakwaterowania i usług restauracyjnych, przede wszystkim ze względu na zakładaną modyfikację przepisów odnoszących się do nich i plan zwiększenia, co prawda w stosunkowo niewielkim stopniu, zakresu prawa do odliczenia, a tym samym neutralności VAT. Wybrane ograniczenie zostało ocenione pod kątem weryfikacji hipotezy, zgodnie z którą utrzymywanie ograniczeń prawa do odliczenia podatku od towarów i usług naliczonego podporządkowane jest celom fiskalnym. 
Możliwość stosowania ograniczenia zakresu prawa do odliczenia podatku naliczonego dotyczącego usług noclegowych i gastronomicznych była, co do zasady, efektem przyznanego na podstawie VI Dyrektywy VAT $^{4}$ prawa do kontynuowania zasad obowiązujących przed przystąpieniem Polski do UE w zakresie ograniczenia prawa do odliczenia, z wyłączeniem nabycia gotowych posiłków przeznaczonych dla pasażerów przez podatników świadczących usługi przewozu osób. Ograniczenie to stosuje się niezależnie od sposobu wykorzystania nabytych usług. Innymi słowy, wykorzystanie nabytych usług noclegowych lub gastronomicznych do celów opodatkowanej działalności gospodarczej nie uprawnia podatnika do pomniejszenia podatku należnego o zawarty w cenie nabywanych usług podatek naliczony w sposób analogiczny do innych wydatków podatnika.

Przepis ten $\mathrm{w}$ niemal niezmienionym brzmieniu jest kontynuacją rozwiązania prawnego obowiązującego od momentu wprowadzenia do polskiego systemu prawnego podatku od towarów i usług, tj. od 1993 r. Pod koniec 2020 r. Ministerstwo Finansów zapowiedziało zmiany w odniesieniu do przepisów poszerzających zakres neutralności VAT. Planuje się bowiem, aby ograniczenie odliczenia nie dotyczyło podatku naliczonego przy nabyciu usług noclegowych w celu ich dalszej odprzedaży. Brak prawa do odliczenia podatku naliczonego w takich sytuacjach był szczególnie dotkliwy dla podmiotów z branży hotelowej, w której powszechną praktyką, przynajmniej do niedawna, była rezerwacja miejsc noclegowych w liczbie przekraczającej dostępną liczbę pokoi (z założenia bowiem określona liczba rezerwujących nie korzysta $z$ dokonanej rezerwacji i nie dociera na miejsce). Jeżeli jednak przyjęte założenia dotyczące liczby przyjeżdżających okazywały się nietrafione (tj. przyjeżdżało więcej osób, niż było dostępnych miejsc), hotel oferował zazwyczaj nocleg w najbliższej możliwej lokalizacji, czyli nabywał usługi noclegowe od innego hotelu w celu wyświadczenia przez siebie usługi noclegowej. VAT od takiej usługi nabytej przez hotel nie podlega odliczeniu. Planowana nowelizacja ma zmienić tę sytuację. Podstawową przyczyną istnienia ograniczeń prawa do odliczenia w odniesieniu do usług noclegowych i gastronomicznych są względy budżetowe i ryzyko nieuprawnionego wykorzystywania prawa do odliczenia w przypadku braku związku z prowadzoną działalnością gospodarczą.

4 VI Dyrektywa Rady 77/388/EWG z dnia 17 maja 1977 r. w sprawie harmonizacji przepisów Państw Członkowskich w zakresie podatków obrotowych - wspólny system podatku od wartości dodanej: ujednolicona podstawa wymiaru podatku (Dz. Urz. WE L 145 z dnia 13 czerwca 1977 r., s. 1), dalej: VI Dyrektywa. 
Brak takiego związku jest konsekwencją korzystania z tego rodzaju usług wyłącznie lub w znacznej części do celów prywatnych.

Efekt budżetowy ograniczenia prawa do odliczenia przeanalizowano w odniesieniu do kategorii wydatków, w przypadku których związek z działalnością opodatkowaną podatnika i zasada neutralności powinny prowadzić do przyznania podatnikowi prawa do obniżenia podatku należnego. W szczególności założenie to dotyczy podróży służbowych i dokonywanych w czasie ich trwania wydatków na zapewnienie noclegu i gastronomicznych, tj. wydatków ponoszonych na zakup usług w restauracjach, kawiarniach czy barach. Zebrane przez Główny Urząd Statystyczny (GUS) dane (do 2013 r. publikowane w odstępach czteroletnich, a od 2013 r. corocznie), pozwalają na podział wydatków dokonywanych w trakcie podróży krajowych na cztery główne kategorie:

- usługi związane z zakwaterowaniem (tj. usługi noclegowe, do których odwołuje się ustawa o podatku od towarów i usług),

- usługi związane z wyżywieniem w restauracjach, kawiarniach, barach i podobnych punktach gastronomicznych (będące odpowiednikiem usług gastronomicznych z ustawy o podatku od towarów i usług),

- usługi transportowe oraz

- zakup towarów.

Pozostałe wydatki dokonywane w trakcie podróży zostały sklasyfikowane w jednej pozycji, jako „pozostałe usługi”. Szczegółowe dane dotyczące skali wydatków ponoszonych przez mieszkańców Polski w trakcie podróży krajowych w wybranych latach, tj. w 2005, 2009, 2013 i 2014 r., w podziale na wymienione kategorie zostały przedstawione w tabeli 2.

Tabela 2. Wydatki turystyczne na podróże krajowe mieszkańców Polski w wieku 15 lat lub więcej według rodzaju wydatku w wybranych latach w okresie 2005-2014 (w mln zł)

\begin{tabular}{|l|c|c|c|c|}
\hline \multicolumn{1}{|c|}{ Rodzaj wydatku } & 2005 & 2009 & 2013 & 2014 \\
\hline Zakwaterowanie & 1214,6 & 2474,3 & 1732,1 & 4899,3 \\
\hline $\begin{array}{l}\text { Wyżywienie w restauracjach, } \\
\text { kawiarniach, barach itp. }\end{array}$ & 2320,1 & 3291,7 & 2644,1 & 5191,3 \\
\hline Transport & 1529,1 & 2422,4 & 2990,4 & 3382,9 \\
\hline Zakup towarów & 1069,3 & 1486,9 & 742,2 & 2511,7 \\
\hline Pozostałe usługi & 661,9 & 775,6 & 519,6 & 979,1 \\
\hline
\end{tabular}

Źródło: opracowanie własne na podstawie http://stat.gov.pl 
Dane przedstawione w tabeli 2 dotyczą wszystkich podróży krajowych mieszkańców Polski, niezależnie od przyczyny wyjazdu, poza miejsce zamieszkania. Dopiero zestawienie tych kwot z danymi dotyczącymi struktury podróży według głównego celu podróży pozwala na oszacowanie wysokości wydatków mieszkańców Polski na usługi noclegowe i gastronomiczne ponoszone podczas podróży służbowych. Dane prezentowane przez GUS pozwoliły na podział wydatków według następujących celów podróży:

- wypoczynek, rekreacja, wakacje,

- odwiedziny u krewnych lub znajomych,

- zdrowotny,

- religijny, pielgrzymka,

- edukacyjny,

- zakupy,

- służbowy oraz

- inny.

Dysponując zatem danymi dotyczącymi wysokości ponoszonych w trakcie służbowych podróży wydatków na usługi noclegowe i gastronomiczne, można wyliczyć kwotę nieodliczanego podatku naliczonego zawartego w cenie tych usług. Odpowiednie dane za poszczególne lata w badanym okresie zostały zaprezentowane w tabeli 3, przy czym w celu wyliczenia kwoty podatku od towarów i usług przyjęto założenie, że pełna wartość nabywanych usług jest opodatkowana według stawki obniżonej (tj. do końca 2010 r. 7\%, a od 2011 r. 8\%). Założenie to jest, co do zasady, prawidłowe w odniesieniu do usług hotelowych. W przypadku usług gastronomicznych założenie o stosowaniu wyłącznie stawki obniżonej może prowadzić jedynie do zaniżenia kwoty nieodliczonego podatku od towarów i usług. Zgodnie bowiem z obowiązującymi przepisami (których treść nieznacznie zmieniała się w badanym okresie),

Tabela 3. Kwota nieodliczonego podatku od towarów i usług w wydatkach służbowych

na podróże krajowe (krótko- i długookresowe) mieszkańców Polski w wieku 15 lat lub więcej według rodzaju wydatku w wybranych latach w okresie 2005-2014 (w mln zł)

\begin{tabular}{|l|c|c|c|c|}
\hline \multicolumn{1}{|c|}{ Rodzaj wydatku } & 2005 & 2009 & 2013 & 2014 \\
\hline Zakwaterowanie & 4,44 & 1,26 & 4,48 & 9,59 \\
\hline $\begin{array}{l}\text { Wyżywienie w restauracjach, kawiar- } \\
\text { niach, barach itp. }\end{array}$ & 8,68 & 1,73 & 6,47 & 10,59 \\
\hline
\end{tabular}

Źródło: opracowanie własne na podstawie http://stat.gov.pl 
obniżona stawka podatku od towarów i usług ma zastosowanie do usług gastronomicznych, z wyłączeniem sprzedaży m.in. napojów alkoholowych.

To wyłączenie oznacza, że usługa gastronomiczna jest niejednolicie opodatkowana - w części stawką obniżoną, w części podstawową. W konsekwencji efektywna stawka podatku od towarów i usług dla usług gastronomicznych rozumianych jako całość będzie nieco wyższa niż przyjęta w celu wyliczenia kwot nieodliczonego podatku od towarów i usług w podróżach służbowych dla tego rodzaju usług.

Z dokonanych wyliczeń zaprezentowanych w tabeli 3 wynika, że w badanych latach kwota nieodliczonego podatku od towarów i usług w przypadku usług noclegowych wahała się między 1,26 mln zł w 2009 do 9,59 mln zł w 2014 r. Dla usług gastronomicznych lata najmniejszej i największej kwoty nieodliczonego podatku są takie same, a wysokość tego podatku wynosiła odpowiednio 1,73 mln zł i 10,59 mln zł. Jeżeli zaś uwzględni się obie kategorie wydatków, kwota nieodliczanego podatku od towarów i usług z tytułu wydatków na usługi noclegowe i gastronomiczne w trakcie podróży służbowych mieszkańców Polski wahała się między 2,99 mln zł w 2009 a 20,17 mln zł w 2014 r.

Poza wydatkami rezydentów na podróże służbowe i ponoszonymi w ich trakcie kosztami noclegów i wyżywienia dla oszacowania konsekwencji dla budżetu państwa istniejących ograniczeń prawa do odliczenia duże znaczenie mają również wydatki nierezydentów w tym zakresie. Metodyka wyliczania kwoty podatku naliczonego niepodlegającego odliczeniu jest identyczna jak dla wydatków ponoszonych przez rezydentów. Kwoty wydatkowane przez nierezydentów na podróże służbowe do Polski podzielono na określone kategorie i wyodrębniono wydatki na:

- zakwaterowanie oraz

- $\quad$ wyżywienie w restauracjach, kawiarniach, barach itp.

Szczegółowe dane zawiera tabela 4.

W ramach tych kategorii, biorąc pod uwagę strukturę podróży ze względu na główny cel podróży do Polski, wyliczono kwotę wydatków na zakwaterowanie i wyżywienie w ramach podróży służbowych. Następnie, uwzględniając wysokość stawki podatku od towarów i usług dla obu kategorii usług (przyjmując zasadę jednolitej stawki podatku stosowanej dla obu usług), obliczono kwotę podatku niepodlegającego odliczeniu (tab. 5). 
Tabela 4. Kwota wydatków nierezydentów w zakresie zakwaterowania i usług gastronomicznych w związku z podróżami do Polski w wybranych latach w okresie 2005-2014 (w mln zł)

\begin{tabular}{|c|c|c|}
\hline Rok wydatku & Zakwaterowanie & $\begin{array}{c}\text { Wyżywienie } \\
\text { w restauracjach, } \\
\text { kawiarniach, barach, itp. }\end{array}$ \\
\hline 2005 & 3508,3 & 2930,0 \\
\hline 2009 & 2300,9 & 2256,4 \\
\hline 2013 & 5007,8 & 5437,0 \\
\hline 2014 & 3914,9 & 2856,0 \\
\hline
\end{tabular}

Źródło: opracowanie własne na podstawie http://msit.gov.pl

Tabela 5. Kwota niepodlegającego odliczeniu podatku od towarów i usług zawartego w wydatkach nierezydentów $\mathrm{z}$ tytułu zakwaterowania i usług związanych z wyżywieniem w związku z podróżami służbowymi do Polski w wybranych latach w okresie 2004-2014 (w mln zł)

\begin{tabular}{|c|c|c|c|}
\hline Rok & Zakwaterowanie & $\begin{array}{r}\text { Wyżywienie } \\
\text { w restauracjach, } \\
\text { kawiarniach, barach itp. }\end{array}$ & Eącznie \\
\hline 2005 & 62,2 & 51,9 & 114,1 \\
\hline 2009 & 40,6 & 39,9 & 80,5 \\
\hline 2013 & 85,3 & 92,6 & 177,9 \\
\hline 2014 & 53,9 & 39,3 & 93,3 \\
\hline
\end{tabular}

Źródło: opracowanie własne na podstawie danych opublikowanych na stronach msit.gov.pl

Z dokonanych analiz wynika, że kwota nieodliczonego przez nierezydentów podatku od towarów i usług $\mathrm{z}$ tytułu usług noclegowych wahała się w przedziale 53,9 mln zł w 2014 do 85,3 mln zł w 2013 r. Dla usług gastronomicznych kwota podatku niepodlegająca odliczeniu była najniższa w 2014 r. (39,3 mln zł), a najwyższa w 2013 r. (92,6 mln zł).

Funkcjonowanie ograniczenia odliczenia podatku naliczonego przy zakupie usług noclegowych i gastronomicznych ma wymierny efekt finansowy dla budżetu państwa. Efekt ten jest widoczny nawet przy założeniu, że część wydatków dokonywana była przez podmioty nieuprawnione do odliczenia podatku naliczonego (ze względu na zwolnienie podmiotowe) oraz w związku z działalnością zwolnioną lub pozostającą poza zakresem 
opodatkowania. Tym samym uprawnione jest twierdzenie, że utrzymywanie ograniczeń prawa do odliczenia w odniesieniu do usług noclegowych i gastronomicznych zwiększa wpływy do budżetu państwa. Wartość tych wpływów jest zmienna i w dużej mierze zależy od skłonności zarówno rezydentów, jak i nierezydentów do podróży oraz od koniunktury gospodarczej.

W tabeli 6 podsumowane zostały łączne kwoty podatku od towarów i usług naliczonego $\mathrm{z}$ tytułu nabycia usług zakwaterowania oraz usług gastronomicznych niepodlegającego odliczeniu za lata 2005, 2009, 2013 i 2014, stanowiące efektywnie korzyść dla budżetu państwa z funkcjonowania ograniczenia prawa do odliczenia.

Tabela 6. Kwota niepodlegającego odliczeniu podatku od towarów i usług zawartego w wydatkach służbowych na podróże krajowe mieszkańców Polski oraz nierezydentów według rodzaju wydatku w wybranych latach w okresie 2005-2014 (w tys.)

\begin{tabular}{|l|c|r|r|r|r|}
\hline \multicolumn{1}{|c|}{ Wyszczególnienie } & $\begin{array}{c}\text { Rodzaj } \\
\text { podróży }\end{array}$ & 2005 & 2009 & 2013 & 2014 \\
\hline $\begin{array}{l}\text { Wydatki z tytułu zakwate- } \\
\text { rowania }\end{array}$ & $\mathrm{A}$ & 4440 & 1260 & 4480 & 9590 \\
\cline { 2 - 6 } & $\mathrm{B}$ & 62200 & 40600 & 85300 & 53900 \\
\hline Łącznie & $\mathrm{A}+\mathrm{B}$ & 66640 & 41860 & 89780 & 63490 \\
\hline $\begin{array}{l}\text { Wydatki z tytułu wyży- } \\
\text { wienia w restauracjach, } \\
\text { kawiarniach, barach itp. }\end{array}$ & $\mathrm{A}$ & 8680 & 1730 & 6470 & 10590 \\
\cline { 2 - 6 } Łącznie & $\mathrm{B}+\mathrm{B}$ & 60580 & 41630 & 99070 & 49890 \\
\hline Łącznie wszystkie wydatki & & 127220 & 83490 & 188850 & 113380 \\
\hline
\end{tabular}

Legenda:

A - wydatki służbowe na podróże krajowe mieszkańców Polski

B - wydatki służbowe na podróże krajowe nierezydentów

Źródło: opracowanie własne na podstawie danych opublikowanych na stronach http://stat. gov.pl oraz http://msit.gov.pl

W tabeli 7 natomiast zawarto informacje dotyczące zarówno dochodów budżetowych, jak i wysokości deficytu budżetowego za wskazane lata. Z porównania tych danych $\mathrm{z}$ danymi zawartymi $\mathrm{w}$ tabeli 6 otrzymano udział podatku od towarów i usług niepodlegającego odliczeniu w dochodach budżetowych. Udział ten wahał się w przedziale od 0,08\% w 2009 do 0,17\% w 2007 i 2013 r. Z kolei w odniesieniu do deficytu budżetowego udział ten kształtował się w przedziale od 0,35\% w 2009 do $0,45 \%$ w 2005 i 2013 r. 
Tabela 7. Udział niepodlegającego odliczeniu podatku od towarów i usług z tytułu zakwaterowania i wyżywienia w restauracjach, kawiarniach, barach itp. w dochodach budżetowych oraz w deficycie budżetowym w wybranych latach w okresie 2005-2014

\begin{tabular}{|c|c|c|c|c|}
\hline Wyszczególnienie & 2005 & 2009 & 2013 & 2014 \\
\hline $\begin{array}{l}\text { Dochody budżetu państwa } \\
\text { z tytułu podatku od towa- } \\
\text { rów i usług (w tys. zł) }\end{array}$ & 75401029 & 99454721 & 113411541 & 124262243 \\
\hline $\begin{array}{l}\text { Deficyt budżetu państwa } \\
\text { (w tys. zł) }\end{array}$ & 28360700 & 23844979 & 42194081 & 28976820 \\
\hline $\begin{array}{l}\text { Udział niepodlegającego } \\
\text { odliczeniu podatku od } \\
\text { towarów i usług z tytułu za- } \\
\text { kwaterowania w dochodach } \\
\text { budżetowych (w \%) }\end{array}$ & 0,09 & 0,04 & 0,08 & 0,05 \\
\hline $\begin{array}{l}\text { Udział niepodlegającego } \\
\text { odliczeniu podatku od } \\
\text { towarów i usług z tytułu } \\
\text { wyżywienia w restaura- } \\
\text { cjach, kawiarniach, barach } \\
\text { itp. w dochodach budżeto- } \\
\text { wych (w \%) }\end{array}$ & 0,08 & 0,04 & 0,09 & 0,04 \\
\hline $\begin{array}{l}\text { Łącznie z tytułu obu kate- } \\
\text { gorii wydatków (w \%) }\end{array}$ & 0,17 & 0,08 & 0,17 & 0,09 \\
\hline $\begin{array}{l}\text { Udział niepodlegającego } \\
\text { odliczeniu podatku od } \\
\text { towarów i usług z tytułu } \\
\text { zakwaterowania w deficycie } \\
\text { budżetowym (w \%) }\end{array}$ & 0,23 & 0,18 & 0,21 & 0,22 \\
\hline $\begin{array}{l}\text { Udział niepodlegającego od- } \\
\text { liczeniu podatku od towarów } \\
\text { i usług z tytułu wyżywienia } \\
\text { w restauracjach, kawiar- } \\
\text { niach, barach itp. w deficycie } \\
\text { budżetowym (w \%) }\end{array}$ & 0,21 & 0,17 & 0,23 & 0,17 \\
\hline $\begin{array}{l}\text { Łącznie z tytułu obu kate- } \\
\text { gorii wydatków (w \%) }\end{array}$ & 0,45 & 0,35 & 0,45 & 0,39 \\
\hline
\end{tabular}

Źródło: opracowanie własne na podstawie danych dostępnych na stronie http://mf.gov.pl 
Z przeprowadzonej analizy wynika, że w ramach przyjętych założeń ograniczenie prawa do odliczenia podatku naliczonego przy nabyciu usług w zakresie zakwaterowania i usług gastronomicznych ma pewne znaczenie dla budżetu państwa. Udział korzyści budżetu państwa, rozumianej jako kwota podatku od towarów i usług naliczonego niepodlegająca odliczeniu w dochodach budżetowych $\mathrm{z}$ tytułu tego podatku, z całą pewnością jest jednak istotnie niższy niż odpowiedni udział w przypadku innych kategorii wydatków, np. dla samochodów osobowych i paliw, przede wszystkim ze względu na skalę dokonywanych zakupów.

4. MoŻLIWE KIERUNKI ZMIAN W ZAKRESIE PODATKU OD TOWARÓW I USŁUG ZWIĘKSZAJĄCE POZIOM REALIZACJI ZASADY NEUTRALNOŚCI

Neutralność podatku od towarów i usług powinna być rozważana przede wszystkim w kontekście zasad funkcjonowania wspólnego systemu podatku od wartości dodanej wynikających z Dyrektywy 2006/1125. Dyrektywa ta narzuca bowiem kryteria i warunki, na jakich podatnik powinien być pozbawiany ciężaru podatku, a jego ekonomiczny koszt ponoszony przez ostatecznego konsumenta. Neutralność tak rozumiana wiąże się przede wszystkim z przyznaniem podatnikowi prawa do obniżenia podatku należnego o podatek naliczony, o ile nabywane towary lub usługi związane są z prowadzoną działalnością opodatkowaną. Niejako odwrotną stroną tego uprawnienia jest brak ograniczeń pozbawiających podatnika prawa do odliczenia.

Rozważając możliwe kierunki zmian zwiększających poziom neutralności podatku od towarów i usług, ewentualną przestrzeń zmian kreują funkcjonujące obecnie ograniczenia prawa do odliczenia podatku naliczonego. Dążenie do zwiększenia poziomu neutralności mogłoby dotyczyć ograniczenia prawa do odliczenia przy nabyciu usług noclegowych i gastronomicznych. W przypadku usług noclegowych, zwłaszcza usług nabywanych wyłącznie w związku z prowadzoną działalnością gospodarczą, podatnikowi powinno przysługiwać prawo do obniżenia podatku należnego o podatek naliczony. Co prawda przepisy VI Dyrektywy dopuszczały możliwość kontynuowania ograniczeń obowiązujących przed przystąpieniem

${ }^{5}$ Dyrektywa Rady 2006/112/WE z dnia 28 listopada 2006 r. w sprawie wspólnego systemu podatku od wartości dodanej (Dz. Urz. UE L 347 z dnia 11 grudnia 2006 r., s. 1), dalej: Dyrektywa 2006/112. 
Polski do UE, niemniej jednak wydaje się, że uprawnienie to wskazywało raczej wydatki na artykuły luksusowe, rozrywkę lub wydatki reprezentacyjne. Tymczasem usługi noclegowe w obecnie - globalnie - prowadzonej działalności są podstawowym wydatkiem, a nie przejawem luksusu.

Wątpliwości, w aspekcie zasadności utrzymywania obecnie obowiązującego pełnego ograniczenia prawa do odliczenia w odniesieniu do analizowanej kategorii wydatków, budzą przede wszystkim usługi noclegowe. Wprowadzanie ograniczeń prawa do odliczenia ma sens, jeżeli:

- $\quad$ wydatek ze swej natury ma charakter prywatny i nie wykazuje żadnego związku z prowadzoną działalnością gospodarczą lub związek ten ma charakter ograniczony, a tym samym prowadzi w efekcie do ostatecznej konsumpcji;

- $\quad$ wydatek ma charakter dualny, tzn. może być dokonany zarówno na cele prywatne, jak i na cele związane z prowadzoną działalnością gospodarczą, ale nie istnieją łatwe mechanizmy kontrolne po stronie organów podatkowych pozwalające zweryfikować zasadność odliczenia podatku naliczonego lub opodatkowania ostatecznej konsumpcji.

Usługi zakwaterowania (noclegowe) z całą pewnością mogą być usługami wykorzystywanymi w ramach prowadzonej działalności gospodarczej, np. w ramach podróży służbowych prowadzonych przez przedsiębiorców. Zdrugiej strony niewątpliwie znaczna część tego rodzaju usług jest wykorzystywana do zaspokojenia indywidualnych potrzeb ludności związanych z podróżami innymi niż służbowe, czyli podróżami o charakterze prywatnym. Niemniej jednak wydaje się, że usługi te pod względem łatwości i skuteczności zapewnienia prawidłowości rozliczeń, tzn. zapewnienia opodatkowania ostatecznej konsumpcji, nie odbiegają od wydatków na zakup samochodów osobowych czy innych wydatków związanych z takimi samochodami. W ich przypadku od początku członkostwa Polski w UE ustawodawca dopuszcza możliwość przynajmniej częściowego odliczenia podatku naliczonego. Obecnie obowiązujące przepisy pozwalają nawet na pełne obniżenie podatku należnego o podatek naliczony, o ile dany pojazd samochodowy wykorzystywany jest wyłącznie do działalności gospodarczej, a podatnik prowadzi stosowną ewidencję potwierdzającą istnienie takiego związku czy sposoby wykorzystywania. Z tego względu wydaje się zasadne przyjęcie rozwiązań analogicznych do tych obowiązujących obecnie w odniesieniu do samochodów osobowych. W praktyce oznaczałoby to konieczność rezygnacji z pełnego ograniczenia prawa do obniżenia podatku należnego o podatek naliczony zawarty w cenie nabywanych usług noclegowych i wprowadzenie częściowego lub pełnego odliczenia. Dokonanie takich 
zmian legislacyjnych byłoby zgodne z prawem unijnym i nie wymagałoby uzyskiwania żadnych zgód ze strony Komisji Europejskiej. Z orzecznictwa Trybunału Sprawiedliwości UE wydanego na gruncie art. 17 ust. 6 VI Dyrektywy (obecnie art. 176 Dyrektywy 2006/112) wynika bowiem, że państwa członkowskie mogą zachować wyłączenia prawa do odliczenia obowiązujące przed przystąpieniem danego państwa do UE lub przed wejściem w życie przepisów VI Dyrektywy. Niemniej jednak państwo członkowskie może zmniejszać zakres ograniczenia prawa do obniżenia podatku należnego o podatek naliczony, dążąc tym samym do realizacji zasady neutralności podatku w większym lub w pełnym zakresie.

Decyzja o zwiększeniu zakresu neutralności i przyznaniu podatnikom w pewnej części prawa do odliczenia podatku naliczonego nie pozostaje bez wpływu na funkcję fiskalną podatku od towarów i usług. Skala wpływu na dochody budżetu państwa z tytułu tego podatku zależeć będzie przede wszystkim od przyjętych rozwiązań prawnych w tym zakresie. Możliwe jest przyjęcie wyłącznie pełnego odliczenia w przypadku wykazania wyłącznego związku nabytej usługi z działalnością gospodarczą lub uzupełnienie takiej regulacji o prawo do częściowego odliczenia w przypadku mieszanego wykorzystania zarówno do celów działalności gospodarczej, jak i do celów prywatnych, jeżeli nie ma możliwości precyzyjnego rozdzielenia usług na te dwa cele. Możliwe scenariusze przyznania prawa do odliczenia zostały podsumowane w tabeli 8 .

Tabela 8. Możliwe scenariusze przyznania podatnikom prawa do odliczenia podatku naliczonego przy nabyciu usług noclegowych

\begin{tabular}{|l|l|l|l|}
\hline Scenariusz & $\begin{array}{c}\text { Zakres związku } \\
\text { z działalnością } \\
\text { gospodarczą }\end{array}$ & $\begin{array}{c}\text { Zakres prawa } \\
\text { do odliczenia }\end{array}$ & \multicolumn{1}{|c|}{ Komentarz } \\
\hline Opcja 1 & $\begin{array}{l}\text { Usługa wykorzysty- } \\
\text { wana wyłącznie do } \\
\text { działalności gospo- } \\
\text { darczej podatnika }\end{array}$ & $\begin{array}{l}\text { Pełne prawo } \\
\text { do odliczenia }\end{array}$ & $\begin{array}{l}\text { Wykorzystanie usługi } \\
\text { w jakiejkolwiek części do } \\
\text { celów prywatnych pozba- } \\
\text { wia podatnika prawa do } \\
\text { odliczenia w całości }\end{array}$ \\
\hline Opcja 2 & $\begin{array}{l}\text { Usługa wykorzysty- } \\
\text { wana zarówno do } \\
\text { działalności gospo- } \\
\text { darczej, jak i do } \\
\text { celów prywatnych }\end{array}$ & Odliczenie częściowe & $\begin{array}{l}\text { Wykorzystanie usługi do } \\
\text { celów prywatnych nie } \\
\text { wiąże się z koniecznością } \\
\text { opodatkowania nieod- } \\
\text { płatnego świadczenia } \\
\text { usług }\end{array}$ \\
\hline
\end{tabular}

Źródło: opracowanie własne. 
Poza celem zwiększenia neutralności VAT, przyznanie przynajmniej częściowego prawa do odliczenia podatku naliczonego w odniesieniu do usług gastronomicznych i noclegowych może mieć jeszcze jeden pozytywny dla budżetu państwa efekt. Przyznanie prawa do odliczenia będzie stanowiło niewątpliwie bodziec dla nabywców tego rodzaju usług żądania dokumentu (faktury) potwierdzającego nabycie usługi i uprawniającego do odliczenia. To zaś będzie zmuszało podmioty świadczące tego rodzaju usługi do ich wykazywania w ewidencji i deklaracji VAT oraz płacenia podatku z tego tytułu. Dlatego warto, by Ministerstwo Finansów rozważyło wprowadzenie proponowanych zmian, choćby na krótki czas, pozwalający ocenić pozytywne skutki takiego działania.

\section{BIBLIOGRAFIA}

Aizenman J., Jinjarak Y., The Collection Efficiency of the Value Added Tax: Theory and International Evidence, „The Journal of International Trade \& Economic Development" 2006, nr 15/2, https://doi.org/10.3386/w11539

Famulska T., Teoretyczne i praktyczne aspekty funkcjonowania podatku od wartości dodanej, Katowice 2007.

Hybka M.M., Determinanty wydajności fiskalnej podatku od wartości dodanej w Niemczech, Poznań 2011.

James K., The Rise of the Value-Added Tax, Cambridge 2015, https://doi.org/10.1017/ CBO9781107358522

Dyrektywa Rady 2006/112/WE z dnia 28 listopada 2006 r. w sprawie wspólnego systemu podatku od wartości dodanej (Dz. Urz. UE L 347 z dnia 11 grudnia 2006 r.)

VI Dyrektywa Rady 77/388/EWG z dnia 17 maja 1977 r. w sprawie harmonizacji przepisów Państw Członkowskich w zakresie podatków obrotowych - wspólny system podatku od wartości dodanej: ujednolicona podstawa wymiaru podatku (Dz. Urz. WE L 145 z dnia 13 czerwca 1977 r.).

Ustawa z dnia 11 marca 2004 r. o podatku od towarów i usług (tekst jedn. Dz.U. z 2020 r., poz. $106 \mathrm{ze} \mathrm{zm}$.). 


\section{LIMITATION OF VAT DEDUCTIBILITY VERSUS FISCAL FUNCTION OF THE TAX ON GOODS AND SERVICES - SELECTED ISSUES}

Summary. It follows from the analysis that there is some tension between the implementation of the principle of neutrality and the fiscal function of the tax on goods and services as a type of value added tax binding in the European Union. It is true that our legislation should follow EU law, which Poland as EU Member is obliged to follow. Nevertheless, in some areas the Member State has the freedom to form its own tax system. With regard to this freedom, as is clear from the analysis, the basic criterion in the decision process with respect to the change in the tax on goods and services is the fiscal function of the tax. Of course, the need to ensure budget revenue at a certain level will always be a priority for every state authority. However, the fiscal function of the tax on goods and services should always be set against the need to comply with one of the fundamental features of this tax, i.e. the principle of neutrality which means i.a. the right to deduct input VAT on goods and services connected with taxable activity. This shows that the extent to which the principle of neutrality in the construction of the tax on goods and services is followed has a significant impact on the fulfillment of the fiscal function of that tax.

Keywords: neutrality principle, fiscal function, tax on goods and services, value added tax, limitation of VAT deductibility, restaurant services, accommodation services 